\title{
The Pataxó baptism rite at Aragwaksã
}

\author{
Rodrigo de Azeredo Grünewald \\ Unidade Acadêmica de Ciências Sociais - UACS, Programa de Pós-Graduação em Ciências Sociais - \\ PPGCS, Universidade Federal de Campina Grande - UFCG, Campina Grande/PB, Brazil
}

\begin{abstract}
This paper frames the baptism rite conducted at the Aragwaksã ceremony as a performance of the Pataxó Indians undertaken in an inter-cultural arena. Using ethnographic data, the article highlights the participative and creative interaction of Indians and tourists in the execution of the event. Attention will be drawn to the functions of the performance and its semiotic possibilities, but especially to the experiential fact. The ritual has multivocal potential, and the article focuses on how meanings emerge. Culture and indigenous identity are important topics and here the rite is perceived in terms of the communion that it provides, as it involves players and audience in the construction of the authenticity of ethnic and potentially traditional elements among the Pataxó.
\end{abstract}

Keywords: Performance; Ritual; Experience; Tourism; Indigeneity; Pataxó.

\section{O rito do batismo no Aragwaksã Pataxó}

\section{Resumo}

$O$ artigo enquadra o rito do batismo realizado na cerimônia do Aragwaksã como uma performance dos indígenas Pataxó efetivada numa arena intercultural. A partir de dados etnográficos, aborda a interação participativa e criativa de indígenas e turistas na realização do evento, examinando as funções da performance, suas possibilidades semióticas, e especialmente o fator experiencial. O ritual tem potencial multivocal e a análise enfoca os meios que proporcionam a emergência de significados. Cultura e identidade indígena são temas importantes e o rito é destacado pela comunhão que promove entre atores e plateia envolvidos na construção da autenticidade de elementos étnicos e potencialmente tradicionais entre os Pataxó.

Palavras-Chave: Performance; Ritual; Experiência; Turismo; Indianidade; Pataxó. 


\title{
The Pataxó baptism rite at Aragwaksã
}

\author{
Rodrigo de Azeredo Grünewald
}

\section{Introduction}

Aragwaksã is a Pataxó commemorative ceremony that has been held every year since 1999 on August 1. The term Aragwaksã can be used to refer to the "place where the sacred ritual is held", but its primary definition is the "conquest of the sacred place" (or the "day of victory"). The ceremony usually lasts only one day, but in rare cases it may be longer. The Aragwaksã is open to the public and includes the participation of a wide variety of people. The various rituals of which it is composed highlight various dimensions or functions of the ceremony.

The Indians presented in this article are from the Pataxó indigenous people, of whom there are some twelve thousand individuals spread among twenty-five villages in five Indigenous Lands, located in the far Southern coast of the state of Bahia, Brazil. I will focus on the Indians of Coroa Vermelha - a location on the coast in the municipality of Santa Cruz Cabrália, which began to be inhabited by Pataxós in November 1972. In April of the following year, more Pataxó families settled there, under invitation from the municipal government to participate, at that precise location, in the inauguration by the Brazilian government of the landmark for the discovery of Brazil and the first mass celebrated on Brazilian soil by Portuguese colonizers.

Therefore, the Indians have been territorialized there since the early 1970s, coming initially from the "mother-village" of Barra Velha and its surroundings and later from other indigenous settlements. At this time, with the construction of federal highways BR 101 and BR 367 - and with the inauguration of the monuments mentioned - the Pataxó learned to produce crafts for commercial purposes. This became an economic activity that supported their settlement of this location, initiating their urbanization. Since then this urban and commercial village has grown demographically, accompanying a tourist boom in the neighboring municipality of Porto Seguro that began in the 1980 s.

Because of the touristic, residential and commercial growth at the location, the Pataxó needed more territory for agriculture and the extraction of forest products to obtain raw materials for their crafts. Thus, in 1996, they occupied a strip of forest close to the beach for agricultural use. On August 1, 1997 the Pataxó occupied another nearby forest (in the municipality of Porto Seguro), which was threatened by tractors sent by the company that owned the land - placing at risk resources such as piassaba fiber (Attalea funifera Martius), seeds and other forest products that they extracted in their widespread walks. This second portion of occupied forest was to be preserved as a place where they would conduct work dedicated to cultural revitalization. The expectation of an ethnic unity that was being consolidated through a communion between culture and nature would characterize the place as "sacred" to the Pataxó of Coroa Vermelha. Following work with cultural production, a sustainable tourism project was developed that was allied to environmental preservation and the renovation of natural resources.

In April of 1998, the Indigenous Land of Coroa Vermelha was finally demarcated in two areas: one on the beach that included the site of the discovery of Brazil as well as indigenous residences and space for commerce; the other included the two forest areas - one earmarked for agriculture and the other for environmental preservation and "ecotourism" (which was later renamed "ethnotourism"). In this second forest area- with the explicit objective of "experiencing and demonstrating the beauty of our culture and preserving the environment” the Associação Pataxó de Ecoturismo (ASPECTUR) [Pataxó Ecotourism Association] was created and the Ecological Reserve of Jaqueira inaugurated in 1999 to intensify the work of cultural reinvigoration, and allow visits by tourists. 
On August 1, 1999, the Pataxó of Coroa Vermelha celebrated the first Aragwaksã to commemorate the occupation of that "sacred place" with the participation of other indigenous peoples and non-indigenous guests. Since then the Aragwaksã has become established as a tradition of these Indians; a ceremony with broad public fraternization that marks their Indigeneity at this location. Each year the Aragwaksã has become increasingly popular, attracting Pataxó from various villages, Indians of other ethnicities, many tourists (including those who come on commercial tour buses) people related to non-governmental organizations, politicians and non-indigenous people in general, who come "to learn more about the Pataxó culture".

The Aragwaksã ceremony involves various activities and rituals, ranging from walks in the forest with tourists to singing, dancing, "traditional marriages", "baptisms", a "warrior hunt", discourses by leaders and shamans (pajes), sharing of food and similar activities. Much of the commemoration refers to the idea of a cultural conquest, whose "traditional elements" must be conserved, strengthened and transmitted.

In this article, I frame as performance (Schechner 2006), only the rite of baptism that was held at the 16th annual Aragwaksã, on August 1, 2014 and I will evoke the possible functions of this performance amid various meanings that it causes to emerge simultaneously. This rite was conducted for the first time by the Pataxó at this event. During the previous annual edition of the Aragwaksã, in August 2013, some Maxacali Indians, who were there as guests, "passed" on to the Pataxó the idea of the "clay baptism ritual", as the Maxacali said they conducted in their village in the neighboring state of Minas Gerais. Thus, this rite was developed at Jaqueira to be performed at the 2014 festival for the first time.

By framing the baptism, I highlight its singularity among the other rites. When interacting with tourists some Pataxó refer to the baptism as the "sacred ritual". Asad (1993) affirmed that "ritual in the sense of a sacred performance cannot be the place where religious faith is attained, but the manner in which it is (literally) played out" (Asad 1993: 50). Here, however, I am not examining religious faith that involves the celebration of a sacrament, but the idea of "sacred" that appears to relate to the specific ethnicity, to a people who are consecrated through practical experiences with elements elaborated to create a sense of traditional and spiritual wonder.

By tradition, I understand here a conscious model of arrangements of cultural elements that are constituted as references for the identity and history of a group of people. A cultural heritage constituted in this way is an historic processual range of their performances, which express much more than static and substantive elements of a culture existing in a place (or among a group of people). The range of traditional Pataxó performances communicates to them their life experiences as an indigenous people.

I link this perspective to the realm of the anthropology of experience (in which the anthropology of performance is contained) that emerged with the post-modern turn (Turner 1986; 1987; Bruner 1986), and which by focusing on "structurally aloof" elements (Dawsey 2005a: 164), illuminates aesthetic forms through which societies experiment creative possibilities through multiple angles and in a state of situationally established subjunctivity. Within it, as Moore emphasized (1978: 52-53) in an epistemological reference to the complex relationship between social life and its cultural representation, the factor of indeterminacy stands out. For Turner (1986), based on the five moments of the processual structure of the lived experience, performance completes experience in all its complexity. Moreover, performance refers us to "a complex sequence of symbolic acts" (Turner 1987:75) highlighted through dramas that appear as "a kind of metatheatre, that is, a dramaturgical language about the language of ordinary role-playing" (Ibid: 76).

According to Bruner (1986), expressions always involve a culturally and historically contextualized processual activity. The text that flows from it has a transformative character and allows a re-experiencing of cultural heritage through performance, although the "participants in a performance do not necessarily share a common experience or meaning; what they share is only their common participation" 
(Bruner 1986: 11). Bruner affirms that "it is in the performance of an expression that we re-experience, re-live, re-create, re-tell, re-construct, and re-fashion our culture" (Ibid), and people are thus active agents in the historic process of construction of their worlds.

It is also important to emphasize how tourism is part of the Pataxo's everyday life. Most of the audience for the Pataxó cultural representations are tourists. The Pataxó have lived in Coroa Vermelha for forty years selling crafts to tourists at the site designated a landmark to the discovery of Brazil. To recall Dawsey (2005b), who discussed the performatic state of the daily life of the "boias-frias" (seasonal sugar cane workers) - the Pataxó work each day in the huts in Coroa Vermelha where they sell crafts, immersed in a metatheater of daily social life under the cross of the discovery. Not just literally under the cross that marks the site but under the impact of a modern imperialism or a touristic colonialism (Grünewald 2015a). In this context, each year on April 26 (the anniversary of the First Mass celebrated in Brazil) a nongovernmental organization from Santa Cruz Cabrália used to hold a play called the Act of Discovery; to reenact the discovery of Brazil. In this production with actors from the NGO and a local monk, the Indians were supporting actors in a play produced outside the community. The script addressed the arrival of the Portuguese colonizers and culminated in the Catholic baptism of an indigenous child celebrated by a friar for large audiences that filled the stands assembled at the location.

Meanwhile, the Jaqueira Reserve serves as a stage constructed by the Pataxó themselves with the express objective of cultural renovation and (eco)ethnotourism. At this location sketches on the basis of fixed scripts and scenery are enacted, as well as other cultural representations. Rituals and other activities are confined to the Indians and more intimate guests.

In both touristic arenas (Grünewald 2001; 2002; 2003), various senses or meanings can be experienced. Since history is "invariably subjective" (Lowenthal 1985: 216), it is always open to negotiation between the tourists and the local performers. Both embody them through experiences that are far from mere cognitive processes. Thus, by conceptualizing the constructed character of the touristic imaginaries, Chronis (2012) highlights them as constructed narratives that have the capacity to create places that stand out as being fictional. Meanwhile, "the sensorial experiences of the physical bodies of the visitors (and performers in general) would be much more real and constitutive of the understanding of a tourist location and what is enacted there" (Grünewald 2015a: 421).

This brings us close to Edensor (2001) who explores the "metaphor of performance" to investigate activities in tourist spaces, highlighted by the domain of performatic improvisation that they reproduce, challenge and transform. I have identified these areas as a stage model (Grünewald 2012; 2014; 2015a; 2015b), which is not an abstract construction made by the researcher for analytical purposes, but a form of developing tourism that is shaped in practice by the social actors themselves and is empirically observed. Using the example of Jaqueira, the Pataxó of other locations developed a performatic (and highly creative) form of ethnic tourism in arenas that were specifically prepared for this professional activity.

These professional performances, however, are not unconscious and are not related to habits, customs or ways of life of the daily identities. They highlight conscious "traditions" explored in the tourism - which involve a process of continual (re)construction of shared praxis and space. For Edensor (2001), in addition to this, the "tourist space is also (re)produced by tourists, who perform diverse meanings about symbolic places, dramatizing their allegiance to places and kinds of action. For the tourists, the performance maps out individual and group identities, and alludes to imagined geographies of which the stage may be part" (Edensor 2001: 71).

On the other hand, I am reminded of the notion of empty meeting grounds (MacCannell 1992), which are vibrant spaces where people are present and have potential for new subjectivities, consciousness and the emergence of new cultural forms and social relationships. In these spaces, indigenous peoples and tourists 
are actors, but as Bruner (2004a) recalled by establishing the notion of touristic borderzone, "the perceptions of the two groups are not the same, because what for the tourists is a zone of leisure and exoticization is for the natives a site of work and cash income" (Bruner 2004a: 220).

As Bruner did when addressing Maasai performances for tourists (Bruner 2004b), I shall also evoke the production and exhibition of a performance, with its "breadth of meanings, ironies, and ambiguities" (Bruner 2004b: 128), and not methodologically focus on the varied and ephemeral perception of the indigenous peoples and visitors that emerge in such a context. For the case of the Pataxó, if at another time I (Grünewald 2009) applied Rosaldo's (1989) concept of imperialist nostalgia, it was not only to refer to a nostalgia of a native way of life that was usurped by colonization, but, above all, to emphasize the nostalgic function that emerges as a vehicle of communication and empathy in broader and more ambiguous experiences that, through the mote of authenticity, can connect, in performance, the visitors with native identities.

As Bruner (2004b) emphasized, "identities are not given; they are performed by people with agency who have choices" (Bruner 2004b: 142). Moreover, the cultures of these indigenous peoples should not be considered in terms of authentic substantive items because their culture is continuously changing and because there are many variants of a single culture. The elements of Pataxó culture exhibited to tourists are creative expressions of their life and even when they are invented or designed specifically for tourist audiences, there is often no simulation of an original because there is no original; they involve "an example of cultural production in the borderzone" (Bruner 2004a: 227). For this reason, even though at Jaqueira there are intimate spaces reserved for rituals only for the indigenous peoples and not for tourists in general, it is not for us to distinguish (as the Pataxó vernacular also does not), what of their cultural production is made and performed for tourists and what is for themselves. There is, perhaps as Bruner (ibid) said, "slippage" between the restricted (the intimate) and the borderzone. The natives themselves may not be certain what is for them and what is for tourists.

Based on these points of view I continue with a post-modern ethnography that, in addition to not avoiding a masking of outside influences, will seek to evoke juxtapositions, pastiche and functional inconsistency, even celebrating the coexistence of cultural items of various origins in the indigenous performances (Babcock 1999). I also locate the work close to Clifford's (1986) considerations about allegory as a performative ethnographic style that emphasizes figurative elements. That is, a text that - like the name Aragwaksã or the baptism that is performed at it - transmits more meanings beyond those that are presented in literal terms - thus giving wings to our imagination. If the tourists who visit the Pataxó help support an "imagined authenticity" (Clifford 1986: 114) as a nostalgic object of an indigenous cultural integrity, this can only emerge as fiction and by means of the allegoric appropriation of the "pastoral" enactment by the individuals in the audience.

\section{Performance and ritual: background}

Acts of symbolic expression appear to mark the aurora of humanity. Performance may even be perceived, if not as responsible, at least as present in the transposition between nature and culture. There may be a wide variety of purposes or functions of performance, but their composition emphasizes, above all, the "dynamic tension between efficacy and entertainment" (Schechner 2006: 81).

Taylor (2013), has affirmed that "performances function as vital acts of transference, transmitting social knowledge, memory and a sense of identity by means of reiterated behaviors" (Taylor 2013: 9). But even if performance is "based on repetition mimicry, and reproduction to form ethnic, linguistic, and national traditions, it also varies to a great extent" (Korom 2013: 2) each time it is performed. As a function of this 
inevitable variation in performances, their emergent character becomes evident, which refers us "to the dynamic quality of performance that allows each expressive event to be shaped by the interactions between performers and audiences" (Ibid). In fact, if Singer (1972) has already alluded to "cultural performances" in terms of members of a community presenting themselves in public exhibition for others to watch, Georges (1969) went farther by pointing to the dynamic and creative tension between continuity and innovation in function, even recognizing that the audience also has the right and responsibility to act, to be co-performers.

In any case, as Langdon (2007) indicated, based on considerations of Richard Bauman and Roman Jakobson, "performance is an event situated in a particular context, constructed by the participants" (Langdon 2007: 8) in which the poetic function is dominant by highlighting "the mode of expressing the message" and not its content. In each specific situation, given the joint participation of those present, an experience emerges - which integrates the corporal, the emotional, the sensorial and the rational - that generates meanings and values, or in sum, is a conductor of the production of reality.

In the relation between performers and audience, according to Schieffelin (1985), the emergent dimension of the performance goes beyond the text or the structure of the performance itself. The function of the performance, "must be sought further in the emerging relation between the performer and the other participants (and the participants among themselves) while the performance is in progress" (Schieffelin 1985: 722). Therefore, I understand that performance can be instrumentalized by the intention of the actors. First, we can question, for example, what the Pataxó think that they are doing, or what they intend to do with the production of their performances. In the case of the baptism presented here, they refer to it using the term ritual. Thus, before, presenting the baptism at Jaqueira, I explore some of the scholarly thinking about performance and ritual, focusing on their implications and possible approximations with certain spheres of life, especially theater. To do so, I will review classic discussions by Turner and Schechner about the issue.

Since Schism and Continuity in an African Society: a study of Ndembu village life, Turner (1957) proposed the study of ritual symbols as a series in time and perceived the relationship between them in processual terms. Through performance, the ritual symbol is transformed into a factor of social action related to contexts of change which are highlighted by an order of intentionality of the social actors. In this way, the symbols are subject to the variability of life and pass between order and disorder and stand out most in social dramas (Turner 1974). This leads us to consider the scheme this author developed in relation to the dialectic between structure and antistructure in the ritual process (Turner 1969). Between one and another of these structural positions, there is a space of passage, which is characterized as a limbo, through which the social actors creatively pass. If the structure is related to the public order of society, in anti-structure, in a condition of liminality, the actors are associated as a communitas, usually in a manner that is transgressive of the norms present in structured and institutionalized relations. This antistructural space is characterized by creativity, by multivocality and by a state of subjunctivity with a strong potential for change in the structure. It is a space (which is also processual because it carries temporality) that is a generator of metaphors, of the sacred, of art, irony, comedy and of criticism of legal and political structures. It is thus, at liminality, with all its characteristic ambiguity, that social and aesthetic dramas unfold. This is where people, imbued by the spontaneous sense of communitas, symbolically represent momentaneous, ephemeral and alternative roles in relation to structure - and which have potential to act in the innovation and revitalization of society. It is in this space, after all, that people have the liberty to transcend structural limitations. It is the space of rituals par excellence: not only for dealing with the sacred, but also for playing, having fun, fantasizing and creating. 
This scheme developed by Turner applies not only to traditional societies, but also to complex, largescale industrial societies, where much of the antistructural space is characterized by leisure. As academic studies about tourism have shown (Barretto 1995), it was with the advance of the Industrial Revolution, with labor in fixed hours and workers' rights to weekly rest and annual vacations that money earned at work came to be used for touristic leisure in places distant from daily life, where people had freedom to experiment other worlds.

By dealing with modern antistructural spaces, Turner perceives them not as exactly equal to the liminal spaces of traditional societies, and for this reason, he calls them liminoids (Turner 1982) where "far more than in tribal or agrarian rites and ceremonies, the ludic and the experimental are stressed" (Turner 1982: 37). Leisure and entertainment (as goods), in their most optional and heterogeneous forms and processes, being optional and having a great emphasis on individual creations (and authorship), gain strong weight in contrast to the concepts of ritual and efficacy characteristic in traditional societies and that usually refer to a homogeneity of values and behavior. In the latter case, the acts and symbols processed tend to have a mandatory character and emphasize collectivity (and anonymity). But whether a space is liminal or liminoid (and of course in modern plural societies both phenomena coexist), a "liberation of the human capacities of cognition, affect, volition, creativity, etc" is noted (Ibid 1982: 44), which generates individual and collective experiences of communitas - even if it is not stable, homogeneous, based on order, and is a carrier of internal differences, as Steil (1996) showed.

Thus, as Silva (2005) emphasizes, at both the liminal and liminoid a temporary rupture of the flow of life stands out that is marked by symbolic and cultural events that are in the extraordinary dimension of creativity and reflexivity. In keeping with the transdisciplinary perspective of the post-modern turn - which avoids classifications and the paradigms of order - performances (with a status of license) would be precisely the moments of interruption of the social order that occur particularly in empty spaces, that is, in marginal performative spaces that are evocative of multivocal symbols.

Using the perspective of theater and analyzing the relationship between performer and audience, Schechner $(1985 ; 1988)$ prefers to avoid a distinction between rite and theater, perceiving that both categories are of the same nature: they are performances. Nevertheless, the objective of a rite is efficacy; and that of theater is entertainment. Both of these objectives, however, are mixed up so that what is important is to note which is preponderant and which is the intentionality of each. In the first case, there is a predominance of an intention towards transformation (generally of someone's status, of existing conditions, etc.); in the second case, performance is more focused on transportation, that is, when people flow to states that are altered in relation to the usual. But obviously, both phenomena are dynamically interlaced in both ritual situations and in aesthetic performances. In addition, if there is a polarity between efficacy and entertainment, people will classify the performances as ritual or theater, depending, to a large degree on the context and function of the event - of the place, of the circumstances and the proposal. But, the "fact is that no performance is pure efficacy or pure entertainment" (Schechner 2006: 71).

In fact, if performances can contain a large quantity of symbolic elements, how can we know which of them are entertainment (or simply aesthetic) and which are efficacy? Which, in fact, does each intend to trigger and what do they bring about? For whom? Who knows which of the symbols are effective and how they are effective for entertaining or realizing something? How can this be known? How can this be transmitted between actors? And given that the audience is part of the performance, how can meaning be established based on the interaction between actors and audience (with audience here considered to include members participating in a ritual and tourists watching an ethnic spectacle for example)?

The position taken here is in contrast to a perspective that indicates the efficacy of the symbol according to its cognitive bias. In criticism of a structuralist position (or of a symbolism) that seeks to 
analyze the messages that the rituals communicate, Schieffelin (1985) teaches us to see performance (ritual) not as "a text or structure of meanings", but as "an emergent social construction". For Schieffelein, "what renders the performance compelling is not primarily the meanings embodied in symbolic materials themselves..., but the way the symbolic material emerges in the interaction" (Schieffelin 1985: 721).

By recalling that "restored behavior" is the main process of all types of performance, Schechner (2006) tells us that it "is 'out there', separate from 'me". If then the "units of behavior that comprise 'me' were not invented by 'me", this allows me to "experience being 'beside myself"' (Schechner 2006: 28). It is interesting to add the distinction developed by this author between performances that can "make believe" and that can "make one believe". In the first, the distinction between what is real and what is pretend is always clear. In the second, the performances create the social realities that they enact. But an emergent semantic complicity will also depend on the interaction between the actors and the audience in specific contexts and through the most varied means.

In addition, the existence of indigenous societies in which different cultural "streams" (or "cotraditions") (Barth 1984) flow, appears also to raise a question in relation to subjectivation. Obeyeserkere (1981) called "subjective imagery" the "process whereby cultural patterns and symbol systems are put back into the melting pot of consciousness and refashioned to create a culturally tolerated set of images" (Obeyesekere 1981: 169). He affirmed that, "subjective imagery is often protoculture, or culture in the making. While all forms of subjective imagery are innovative, not all of them end up as culture, for the latter depends on the acceptance of the subjective imagery by the group and its legitimation in terms of the larger culture" (Ibid: 169-170).

A tension is also perceived between the individual performative needs for differentiation (or those of small groups) and contrary collective (or orthodox) forces that tend to maintain previously patterned practices. In this tension, the cultural improvisation or experimentation should be processed within certain parameters, even if they are not at all rigid (as in Jaqueira), so that the indigenous audience and that of tourists recognize these traditions as an integral part of a certain characteristically indigenous universe, and, more specifically, Pataxó.

This tension also involves the universe of the rituals, which possess a potential both for stability and for change as a function of their dynamics and the experience that emanate from them. Therefore, according to Schechner (2006), even if rituals change circumstantially, they should always give an "impression of permanence, of 'always having been'. This is their publicly performed face" (Schechner 2006: 72). It is known, however, that "rituals may also be invented - both by official culture and by individuals. In fact, one job of official culture is to make relatively new rituals and the traditions they embody appear old and stable. Such an appearance helps support a sense of social stability" (Ibid: 73). In fact, "the need to build community is fostered by ritual. And if official rituals either do not satisfy or are egregiously exclusive, new rituals will be invented, or older rituals adapted, to meet felt needs" (Ibid: 74). For Schechner, there is no pure and genuine division between sacred and secular rituals.

By highlighting performance as "ritualized behavior conditioned/permeated by play", Schechner advances, affirming that "ritual has seriousness to it, the hammerhead of authority. Play is looser, more permissive - forgiving in precisely those areas where ritual is enforcing, flexible where ritual is rigid" (Ibid: 89). In this way, Schechner has us see that play has strong potential; both of a subversive order, and one that is creative of a multiple reality. As experience, this reality is constructed in flow; or that is, when the limit between the interior self and the activity executed dissolves and "the player becomes one with the playing"' (Ibid: 97). For Turner (1982) - citing Csikszentmihalyi - "flow denotes the holistic sensation present when we act with total involvement" and without the need for a "conscious intervention on our part" (Turner 1982: 55-56). 
When describing the rite of the Pataxó baptism it is thus important to try to capture the experience in flow. But, based on their experience, what do the Pataxó understand about what they do? Dilthey (1976) maintains that "reality only exists for us in the facts of consciousness given by inner experience" (Dilthey 1976: 161). As Bruner (1986) affirmed, "what comes first is experience", which is not limited only to sensitive and or cognitive data. It is on this basis that the anthropology of experience highlighted by Bruner "deals with how individuals actually experience their culture, that is, how events are received by consciousness" (Bruner 1986: 4). It is also worth emphasizing an important distinction this author makes between experience - which is internal, an activity of the self that shapes action, and is personal - and behavior which is external and described by the audience of the event. For Bruner, "the critical distinction here is between reality (what is reality out there, whatever that may be), experience (how that reality presents itself to consciousness), and expressions (how individual experience is framed and articulated)" (Bruner 1986: 6). And as Turner (1986) has indicated, experience is completed through the form of expression, which is precisely the realm of performance, Well, if performance completes experience, what remains available for observation and evaluation of the event by the part of the audience is the behavior and competence of the actors to express a reality (constituted by indigenous experiences in interaction with various audiences), whose construction will depend on the emergent experience in each one of the observers in the situation of estrangement in relation to daily life and possibly even of previous information that supported the reality enacted there.

Finally, passing on to the ethnographic description of the rite of baptism in the Pataxó's Aragwaksã, I also want to emphasize that I will try to keep in mind considerations made by Bauman (1975) concerning analysis of a performatic event - which instructs us to focus on the exhibition of the competent behavior of actors for a participative and critical audience - framed through keyings that metacommunicatively highlight some central moments of the event for the audience, which experiences the actors' sensations, emotions and everything else that fits within human experience.

\section{The Jaqueira Reserve and the baptism in the Aragwaksã}

The Indigenous Land of Coroa Vermelha was approved as such by government in July 1998, encompassing 1,493 hectares divided, as I mentioned above, into two spaces. The urban portion where the discovery site of Brazil is located includes 77 hectares along the ocean beach. The second space is divided in two parts located in two municipalities. The forest area where the Jaqueira Reserve was created has 872 hectares in the municipality of Porto Seguro. Since 1999, this reserve has been open to tourist visitation.

The tourist trips generally follow a single route that the visitors take with indigenous guides. The visit begins at the reception by an Indian at the gate of the Reserve, where the tourists sign a visitors' book, make a payment and receive instructions about the tour. Soon after this entrance post, and passing through the mark of the "sacred river" they continue on a trail in the forest until they reach the center of Jaqueira, where there are some tourist cabanas or huts, most of which are round. At the reserve there is also a school, residential huts, a large kitchen, a hut that is used for intimate rituals exclusive to the indigenous (and rare guests) and a football field. But not all of this is accessible to the tourists.

Upon reaching the center of Jaqueira, in the "large hut" (at the center of which is a statue of an Indian with ritual and decorative elements all around) the tourists are welcomed and hear a talk that describes the history, culture and struggles of the Pataxó, the establishment and meaning of the Jaqueira Reserve and information about the tour. They then walk to the nursery of native plants and the garden of medicinal plants. Afterwards they continue on trails in the forest, stopping to see hunting traps, how a few plants are used, they stop in a hut that represents an old type of Pataxó residence (which was reconstructed based on 
a book from the colonial era) and at another hut that represents the current style of living of those who still live in greater isolation. They see how the Indians sleep, how they prepare their meals on embers and how they use the leaf of the patioba (a native palm - Syagrus Botryophora) to communicate in the forest. There is also a small indigenous museum (with paintings and artifacts) and a hut where crafts are sold (mostly made by Pataxó from Coroa Vermelha, but there are also pieces made by other indigenous peoples or those made at Jaqueira using materials from other places). The visitors are also offered fish roasted in the patioba leaf ("traditional food") with tea, usually brewed with lemongrass (Cymbopogon citratus). Upon returning to the large hut, they happily share native dances. There are also shamanic moments like a session with a person who prays over sick people (rezadeira) or conversations with ritual specialists (pajés), and play with bows and arrows close to the public restrooms. During the visit the discourse presented by the indigenous guides refers to studies conducted with the elders of long lost traditions that have been "revived". Finally, the hosts show the tourists the (post-colonial) symbol of Jaqueira: the fallen trunk of an apparently dead jaqueira (jackfruit tree), from which four new jackfruit trees have grown, representing the indigenous revitalization after colonization.

In addition to the trails in the forest, there are footpaths among the huts at Jaqueira. In front of the large hut, crossing the circulation path of the visitors, is an installation made from five branches joined in the shape of a cone, about four meters tall with a round trunk at the center. Constructed by Maxacali Indians, it is about two meters long and sixty centimeters in diameter, sculpted and colored (painted in white, black, light blue, red and yellow, forming iconographic patterns with diamonds and triangles) and placed vertically on the trunk of a tree - the "trunk of religion" — of about 1.3 meters in diameter, a meter tall and surrounded by bromeliads. At the top of the structure - and at its center - the branches are tied with a thin vine to keep the structure standing. At the top of the structure the vines are also tied around palm leaves (which are always replaced when they dry out), which cover the top, in such a way that the central element remains exposed. At the base, at ground level, surrounding the entire structure, there is a thicker circle of woven vine, whose diameter (of about 2.5 meters) accompanies the branches where they touch the ground. Between this circle on the ground and the bromeliads at the center some sawdust was placed on the ground on the day of the ritual I observed. Close to this installation the Pataxó also placed other elements with "spiritual" significance, such as a large dream catcher. In addition, a fireplace was assembled there with thick tree trunks piled about half a meter tall - as they customarily for leisure or for certain intimate (exclusive) rituals and or for visiting friends. For the Aragwaksã ceremony of 2014, in addition to these elements, a mound of clay was placed outside the circle at the base of the structure of the trunk of religion. The mound of clay was nearly circular, about fifty centimeters in diameter and dark yellow or yellow-ochre in color, which will be simply called ocher. It was there, alongside this structure (between it and the fireplace) and using this ocher clay, that the Pataxó conducted their first "baptism ritual" on August 1, 2014, in the presence of many Indians, guests, visitors and charter tourists.

It appears that a trip through alterity begins at the gate to Jaqueira, which is opened daily to whoever wants to experience the tour. On the day of the Aragwaksã, there is a different tour, specific to this ceremony. In any case, it all begins at the entrance to Jaqueira, whose gate indicates the border between the non-indigenous space of the locality and the indigenous tourist arena, that is, a borderzone where the interculturality is professionally processed. The gate (and the entrance post where the visitors sign their names and receive instructions about the tour) is a limen that leads the visitors to a liminal/liminoid space of ethnic alterity. It is known that all tourism is an intercultural adventure and the tourist activity itself is processed at the liminality, in a space (of leisure, of play), and at an antistructural moment in which the tourists associate as communitas. At Jaqueira, this liminality is extended to the indigenous fact, with an entrance and exit from another ethnic dimension that transports the visitors on trips through imaginary time and space. 
A first impression of the Aragwaksã of 2014 was the turbulent arrival of the tourists, at about 9 AM, in more than two large tourist buses of the large charter tourist company, CVC, and some smaller buses. In addition to these tourists, who gathered in groups (carrying all the tourist paraphernalia such as cameras, knapsacks, etc.) some visitors arrived in their own cars or by other means of transportation. There were also many Indians, some government authorities and representatives of companies. In addition to the visiting Indians in general (from Coroa Vermelha and other villages) - dressed in ordinary clothes (shorts or long pants shirts, tee-shirts, etc.) - those who stood out were the charter tourists, who entered the Reserve in a group that buzzed with commotion as they discussed the novel space and expressed a wide variety of interpretations of the scenery.

The tourists from charter groups took turns during this initial part of the visitation: while one group left for the walk, following the ordinary tour along the trails with the indigenous guides, another group was in the middle of this tour and another was already returning. That is, the groups were sent on the tour in blocks in a well-organized manner so that it all flowed easily. As they returned from the tours in the forest (and concluding the tour with the tasting of fish and tea in one of the huts) they dispersed through the environment of Jaqueira, waiting for the rites of the Aragwaksã to begin. Many gathered in the hut where crafts were sold, others inspected the space, curiously observing the surroundings, others sought to speak with the indigenous people. Many children were encouraged to play with the indigenous kids while others did not let go of their parents' hands. In general, among the leafy trees of the Atlantic Forest, and various indigenous huts, the highly diverse group maintained a spirit of fraternization. Although various vine baskets for garbage are found at Jaqueira for visitors to throw cigarette butts and other waste, a remarkable number of tourists were smoking and indifferent to the cleanliness of the place. Nevertheless, the Pataxó are incapable of reprimanding their visitors, whom they receive very politely.

For the indigenous people, the activity began early in the morning when the Pataxó who work in Jaqueira travelled by car over the seven kilometers from Coroa Vermelha where they live (only one family, including a father, mother and young daughter were living at Jaqueira at the time). On federal highway BR-367 there is an entrance (indicated with an enormous sign with photos of the activities at Jaqueira announcing the ethnotourism conducted there) to the $2 \mathrm{~km}$ dirt road that the cars take to reach the gate of the reserve. Entering Jaqueira, the characteristic smell of the Atlantic Forest close to the sea stands out, the sound of birds, insects and the rustling of leaves in the breeze. The Pataxó began the preparation of the place with simple tasks such as sweeping, cleaning, organizing the huts, cooking, cutting plants, feeding animals (in addition to dogs, parrots and chickens, there is a small cage with a monkey close to the crafts hut). The men and boys dressed, as always, in shorts without shirts, and the women in bikini tops and shorts - clothes suitable to the daily life of a place with an average temperature of $25^{\circ} \mathrm{C}$, as it was on the day of the event. As they checked the trails, the mesca (or amesca-Protium heptaphyllum,) and other items required for the fumigation, they remained in silence, apparently concentrating on the day of work. At this time was observed a moment of their transition, or transportation, to the condition of actors in the performance they would soon perform. Some took the time (mainly women and children) to make crafts, while others painted and placed decorations on their bodies: such as the tupiçai (a straw dress made of taboa - an aquatic plant [Thypha domingensis (Pers.)]), colored rattles, bracelets, necklaces (even some made with beads and the symbols of football teams in their designs), ankle bracelets, arm bracelets - not to mention the bodies already habitually transformed with spacers and piercings made of wood (or animal bones) inserted in chins, lips, nostrils, ears, etc. They also had a variety of hair styles, including those commonly used in the region in various performative styles that signaled a generic tribal meaning. All of this, after all, was in preparation for the play that they would perform, transporting themselves to an ontologically performative dimension of their reality in which they perform an imagined I-we, but that is (re) constructed 
in the enactment itself. The plan for the tours, and the performances themselves, must be obeyed to guarantee the success of the event (its efficacy), which is the public expression of this imagined I-we.

For the production of the event and the direction of the plot and script of the play, an hierarchy was noted among the actors of Jaqueira, delineated by the most experienced who administer the place. But the most important asymmetry to be considered was related to the audience, which should be influenced and satisfied by mimetic behavior of the Pataxó actors. The concept of mimesis as developed by Benjamin (1994) and Taussig (1993) is important here. If the first author affirms that mimesis is the faculty of producing similarity, Taussig specified that it involves the "faculty to copy, imitate, make models, explore difference, yield into and become Other" (Taussig 1993: xiii). Based on the mimetic Pataxó behavior, games of representation are established that are constitutive of their understanding of the world, which is composed, by this means, through the experiences of the actors, making them "sensitive to social representations" (Moraes 2013: 133), or, in Taussig's words, "bringing sensuousness to sense" (Taussig 1993: xiii). According to Moraes, many of the "identities are not only based on ideas that the subjects form of themselves, but also on their experiences of being themselves and of acting in a convenient manner" (Moraes 2013: 133).

The mimesis emerges as a guiding force in the production of a multiplicity of ways to be Indian. This is perceptible in the various ways that the Pataxó paint or adorn their bodies, as well as by their forms of elocution. For there to be homogenization, a certain control of the mimesis is necessary in order to harmonize the group of characters in their different performances and competencies. After all, to make oneself an Indian, in a performance, involves an ordering of the body, of perception, gestures, affections and thoughts. Moraes steers us to this attention through the concept of regency. This is the action of one or more regents that will conduct the polyphony of voices, to establish certain unified meanings. This becomes even more important because the meanings of the performance emerge from the interaction between the actors and the audience. Therefore, the regency must also apply to the audience of tourists (and other visitors to Jaqueira, even the indigenous Pataxó themselves), which is also active in the negotiation of meanings (or in the articulation of the social construction of the reality). After all, a group of interdependencies is needed between actors and audience for the event to be successful.

The authority of an intentional regency, however, does not appear definitive to us because the meanings of the world are also formed by the senses of the body involved in the ephemeral experience of pleasurably penetrating this fantastic indigenous universe. The event begins with the arrival of the tourists. Upon crossing the entranceway to Jaqueira, the visitors enter an environment ripe with entertainment. On the day of the Aragwaksã in particular, the habitual tour is combined with various performances - some staged as "rituals" - that transport the visitors to still deeper places of the fantastic Pataxó life. Here the baptism rite must specifically be framed.

\section{The baptism: between actors and audience}

The baptism that is addressed here is not the religious baptism to which children are submitted in their parents' churches (Catholic or Evangelical in most cases), nor any other baptism ritual created by the Pataxó of Jaqueira to attribute a name to their non-indigenous friends who in some form relate with them very positively - as was the case of the anthropologist who wrote this article, who was baptized twice in intimate rituals and has received two indigenous names. Baptism in the Aragwaksã, does not attribute a name to anyone, nor does it make anyone a member of the ethnic group. It does not change anyone's status. It therefore does not involve a rite of passage (van Gennep 1978). In fact, the baptism in evidence here stands out as an aesthetic act of inter-cultural communion. 
At Aragwaksã, it was with the ocher clay placed alongside the installation of the trunk of religion that children (both visitors and indigenous) were baptized. Thus amid the conglomerate of various people gathered between the large hut and the crafts hut (the two closest to the structure of the trunk of religion), some Indians went to the clay, while an Indian woman alongside the structure of the fireplace began to pass mesca smoke on the visitors. Four elders (three women and one man) then began to mix the clay, breaking up the mound and preparing it for handling during the rite. Seven Indian men emerged from the forest, from behind the restrooms, dressed in tupiçai skirts and different body ornaments (highlighted by various large and mostly red necklaces) marching, in a line dance, emitting monosyllabic shouts, singing in the patxohã language and playing their maracás (indigenous rattles made of gourd [Crescentia cujete] with seeds inside) with their right hands - while four of them carried spears in the other hand. Since the baptism was the first programed act of the Aragwaksã, this appearance of the Indians singing as they entered was important to key to those present that the ceremony was beginning. By arriving while singing, the Indians called attention to the people scattered in the environment to something that would happen in a certain place.

In fact, as they reached the trunk of religion, many tourists followed them with their cameras. At this time, this installation was being fumigated by an Indian woman who circled it carrying in one hand a pot with the smoking material (coal embers with mesca) and holding a granddaughter to her hip on the other side of her body. The Indian men continued to dance and sing in a line around the structure, moving in a clockwise direction, while an increasing number of people gathered around them. The Indians stopped dancing, facing the structure, in the middle of the circle, that is, because there were only seven individuals, they occupied less than half of what would be a complete circle around the trunk of religion installation. Their faces were colored with clay, each one in a different manner, but all in mostly yellow, red and black, The combination of these three colors was in vogue at the time in allusion to the German flag - the country whose team had won the 2014 World Cup that year and which was lodged in the region during the tournament, and interacted regularly with the Pataxó. Not only the body painting, but the adornments on their arms, legs and necks followed the chromatic pattern.

The scene took shape in this way: the ocher mound of clay was on the ground next to the circular installation of the trunk or religion with four elderly Indians around it. The seven Indians who had been dancing had stopped and faced the installation, following those who were squatting next to the clay. Behind the squatting Indians and those who were standing was the fireplace. Finally, a large circle of visitors formed who formed a circle, beginning on the side of the installation opposite from the mound of clay, around the main installation, passing the Indians, behind the fire and the other Indians, and back to the other side of the installation (opposite from the clay).

One Indian (the son of the first Indian woman who was releasing incense), very well adorned with a beautiful ox-bone necklace and a pipe (known as a xanduca, that is, "a sacred pipe" of angico [a typical wood from the semi-arid region - Anadenanthera macrocarpa (Benth.) Brenan] of the Kariri-Xocó Indians from Alagoas state) lit in his mouth, or at times, held in his left hand, began to walk clockwise. He also was spreading incense from amesca resin placed over coal embers in a small rectangular ceramic recipient as he walked behind the backs of the Indians who were standing next to the installation, the fireplace and the Indians squatting around the clay, and the installation of the trunk of religion.

The Indians who had been dancing began again to sing and spin (now in a row joined by an Indian with a small child in his lap and another boy - who was wearing shorts and a tee-shirt) circling around the installation, the fire and the Indians (now with two more helpers) squatting around the clay. The Indian responsible for the incense spent the entire time releasing smoke and puffing his pipe. A large ceramic pot with water was taken to moisten the clay. During the entire rite an Indian stood next to the clay holding this 
pot so that it was constantly moist. The elder responsible for the baptism knelt down on the ground in front of the mound of clay and, with eyes closed, silently prayed amid the loud buzz of people, many pointing their cameras. Two indigenous children about four years old - and adorned with necklaces and other ornaments - stood next to the clay, which was spread on their bodies by the elder Indian and the other three elder women conducting the rite.

It was then the tourists turn. First, one charter tourist from the bus of the CVC company presented her daughter (who was certainly less than one year old) to the Indians responsible for the baptism, who covered her completely with ocher clay from neck to feet, leaving only her head clear. The mother, upon taking back her daughter, clutched her with a proud smile, and held her hanging by her arms for all the other tourists to see and take pictures. Another baby tourist was then passed to the Indians for the baptism and then one more girl about four years old. Both had been previously decorated by their mothers with indigenous crafts purchased at Jaqueira. One more baby tourist - dressed with only a disposable diaper and crying vigorously was covered with clay. Two other girls of about six or seven and dressed as Indians also presented themselves to be covered with ocher clay in the rite underway. The babies were all baptized in silence by those conducting the rite and handling the clay. One of the elder women held them over her extended arms with the baby lying down (first facing up and then downwards), while the elder man passed clay over the child's body. When it was the older girls' turn, they stood up and had their bodies covered with clay by the elder women.

Finally, in a moment of informal dispersal, some of the Indians who were singing removed their necklaces and asked their companions to pass clay on their trunks (stomach, chests and back). Indigenous children not dressed in indigenous style approached the clay and began to play with it without concern at this moment in which the Indian men from the dance and others who appeared painted themselves calmly and happily. All of the acts of this performance were registered not only by tourists but also by many happy indigenous people who, with great interest registered the episodes with cell phones, digital recorders and photographic cameras. The Pataxó are aware of the variation and inconstancy of their knowledge about their ritual world, which should not be understood as a complete and consistent system, but something that is open, with many novelties and opportunities for something new. On many occasions, they were interested in registering these performances for research purposes, periodically to review them and reflect on opportunities for cultural renovation.

While the actors in the baptism (both those who conduct the baptism - and their assistants, who go to the audience to get the children - as well as those who sing and dance - and release incense) remain absorbed in their activities, all of the segments of the audience who approach the baptism to help them express considerable curiosity, joy and enchantment. Meanwhile, the indigenous leaders at Jaqueira and other villages remained far from the baptism, conversing about various issues. In the same way, other Indians (including those from the indigenous education sector, take the opportunity to meet relatives or allies from other villages and remain far from the baptism, also engaged in conversation about recent events. The baptism had an audience of tourists and visitors in general. Without their engagement it seems that this staged "ritual" would not take place. The baptism was not a ritual aimed specifically at the Pataxó, given it was certainly prepared for visitors.

After the tourists dispersed, the group of Indian singers enter the forest and soon return using the trail in front of the large cabana, shouting and singing in a row and carrying bamboo to which is tied a dead pig with its head down and two arrows stuck in its neck (with the shafts pointing up). All of the visitors return once again to this second performance (called the warrior hunt), which continued around the installation of the trunk or religion (keying for those who remained that another performance was heading towards another location), and then moved close to the kitchen, where the pig was placed on the ground and the Indians danced around it. Other performances followed, such as indigenous marriages. 
For these weddings, all of the tourists (or visitors in general) were summoned (and the tourist guides had an important role in leading the tourists to the location) to enter the large cabana, where the indigenous leaders spoke to everyone. The other performances were not openly announced, but were keyed and received spontaneous adhesion from the audience. In the case of the baptism, for example, while many tourists (or visitors in general, indigenous or not), were completely absorbed by the performance, others watched less attentively. Some people were still not watching, holding conversations in various places. That is, the degree of participation of the audience during the baptism rite was highly varied, as there were very likely a variety of meanings that emerged about this performance in the minds of those present, whether among the indigenous actors, visiting indigenous and non-indigenous peoples or tourists who came on charter tourist buses. In reality, even before the performance began, the material elements themselves (such as the fireplace, the installation of the trunk of religion etc.), already evoked various meanings among those present, whether they were active participants or not. In fact, there is a strong presence of materials at Jaqueira and the Aragwaksã - and of performances that are enacted at specific moments - which are characterized by a deep cultural plasticity. This is an arena for hybrid and varied stylistic resources that serve as a guide for new reflexivities and new sensations.

Everything that happened at the Aragwaksã was evaluated by everyone present, who expressed themselves through their bodies, in grimaces, murmurs and other facial expressions, and in discussions ranging from the shallow to profound - about critical elements. For most of the spectators, the ceremony as a whole, and in particular the enactment of the baptism rite, was an absolute success because the intensity of the play performed promoted a holistic sensation of communion with the broad involvement of those present. The engagement of the audience, as Geertz (1978) shows in relation to Balinese cockfights, is important for establishing the thickness of an event, making the performance more absorbing - which is an important goal for the hosts of the festival.

At the performance at Jaqueira, the indigenous peoples and tourists interactively co-create a reality that constantly retextualizes the Indianness and the specific interculturality. The tourists do not pay great attention to the discursive dimensions of the rituals, although the indigenous songs and communications in patxoh $\tilde{a}$ attract attention and stir curiosity, adding a general sense of native energy to the environment. The reality is constructed in the participatory interaction between the performers and the audience (because if the group of visiting tourists expresses indifference upon seeing the cultural elements performed there, they do not fix them as a reality). In this context, the use of the patxohã language has an important role because it establishes a coercive situation of regency of the spectacle (and of construction of reality), whose meanings cannot be completely understood by the audience. Nevertheless - or perhaps for this reason - the audience becomes the arbiter of the "staged authenticity" (MacCannell 1973) in this arena.

In another article (Grünewald 2009) I discussed how authenticity is an experiential and relational issue involving power. What is important to emphasize is that the legitimacy of the performance, as representative of an ethnicity, is not only attested to cognitively. A performance is preceded by the expectations and anxieties of the people for whom it will take place. But it is not sufficient to simply provide information to the audience about the meaning of the ritual, because the audience should remain in movement, curious and absorbed in order to create a link that allows dramatically re-connecting the visitors to a nostalgically latent universe if possible. According to Schieffelin (1985), the ritual

"entices, arouses, and intrigues so that the participant constantly strives to get hold of something that always seems just out of his or her grasp. The performance is gripping not because of the vivid display of symbolic materials but because the symbolic material is incomplete. Reality and conviction reside not in the spirit's message but in the tension produced when some important communication seems at once clear and ambiguous. This experience of inconclusiveness and imbalance gives people little choice but to make their own 
moves of creative imagination if they are to make sense of the performance and arrive at a meaningful account of what is happening. In so doing, however, they complete the construction of its reality" (Schieffelin 1985: 721).

Thus, the performance appears as a vehicle for the social construction of reality and people's convictions appear more as drama than as rational thinking. Shieffelin affirms: "ritual in performance is a reality apart from its participants" (Ibid: 722), who do not necessarily experience "the same significance or efficacy". In this line it can be said that "in the absence of any exegetical canon", there is no "correct' or 'right' meaning for a ritual at all”, because

"The performance is objectively (and socially) validated by the participants when they share its action and intensity no matter what each person may individually think about it. It follows that the meaning of ritual performance is only partly resident in the symbols and symbolic structures of which it is constructed. To a large degree (...) the meanings of the symbols and of the rite itself are created during the performance, evoked in the participants' imagination in the negotiation between the principal performers and the participants” (Ibid).

In this way, the rituals have historicity that is given by the performatic executions that constantly place structures and scripts at risk through the dramatic practice itself. Moreover, the performances at Jaqueira are valorized not for their substantive authenticity, but because they allow the "affective enjoyment of the present" which has the potential to produce a volition that generates a will in relation to the future (Turner 1987: 96). Therefore, I think that through the performative experiences at Jaqueira, the past is reviewed and revalorized in the present to be able to reorient practices and symbols of Pataxó identity. Even if this is processed in touristic arenas, as we have seen.

Bruner (2005) reminds us that "performances for tourists have local histories, change over time, and are constructed especially to be marketed and sold to an audience" (Bruner 2005: 4) who are generally interested "in a good show" and not in authenticity. In fact, he affirms that this issue of authenticity is fallacious to the degree that, as I observed among the Pataxó, "there is no simulacrum because there is no original. Performances for tourists arise, of course, from within the local cultural matrix, but all performances are 'new' in that the context, the audience, and the times are continually changing" (Ibid:5). To seek authenticity in the cultural items enacted is from my perspective a hallucinatory journey, because the images, figures or sensations apprehended are not fixed as an objective reality.

Much to the contrary, the individuals of an audience should note that, both for them and for the indigenous actors, reality is composed by "formative and transformative" experiences (Turner 1986: 35) that can express both the common and unusual (which, according to Turner, also has its traditions). He affirms that, "the point is whether meaningful guidelines emerge from the existential encounter within a subjectivity" (Ibid: 36 ), even if the sense of an absence of meaning is established.

\section{Final Considerations}

When considering daily life at the Indigenous Land of Coroa Vermelha it can be perceived that Jaqueira is the main space where extraordinary performances take place. At Jaqueira, a Pataxó communitas guides the social and aesthetic dramas performed there, whether as rites, rituals, or, in sum, as effective performances that may even seek to entertain (and what was one can become the other). Interlacing ritual and art, a fluidity is noted in the construction of the traditions processed there by the performances that are always open to changes, to creativity. It is therefore an environment that is characterized by the occurrence of liminal and liminoid phenomena (Turner 1982), while, at the same time that they are part of the indigenous ethnicity, are constructed in a post-modern touristic borderzone (Bruner 2004a). Coroa Vermelha is a place where plays that involve a certain risk are performed for various audiences, promoting social experiences 
that are rich in possibilities of meaning for emergent spontaneous communitas. The Pataxó actors articulate both the environment as well as their bodies with the indigenous history and identity which, manipulated through performances, act in the social construction of the Pataxó reality, even through a heterogeneity of the self. That is, under the Indian being is found a multiplicity of varied experiences with a predominance of the plural modes of interacting bodily to the world, in which the individuals particularly imagine and feel themselves to be Indians, based on their own body dispositions.

There are forms of knowing reality that are different from the rational literary Western mode. Among them can be highlighted local knowledge (transmitted orally and by mean of performances) that can encompass various way of consolidation, as through bodies. Schechner (2013) also adds "that 'indigenous knowledge systems' are likely to be performative, embodied. This is what Schechner means by "performance as research" (Schechner 2013: 44). In fact, this is how the Pataxó do research through their performances, which are always mutable, renewable, and invented and that act in the permanent reconstruction of their world, producing shared cultural understandings.

Speaking of paleolithic cave dwellers, Schechner suggests that since their time,

"each specific evanescent performance kept and transmitted the script which was more important than any single re-presentation. The scripts are performance knowledge, life-sustaining knowledge; knowledge that later would be called 'sacred'. And, when so, the performances would be called 'rituals'” (Ibid: 52).

Continuing to follow this author, attention should be paid to the immanence of actions that manifest reality, and not to their symbolic representations, which are always at risk because of the transformative power of performances. Although the baptism at Aragwaksã stems from an idea that came from the outside, from the Maxacali, it is through their own action that the Pataxó construct this new tradition, this new "ritual", as their own reality. They know this reality - with their minds and their bodies - by performing it. Moreover, if the performances can be understood as restored behavior, given that they attend, as Abreu (2013) affirms, "to a reasonably structured script in a sequence of movements in specific scenes that use highly codified elements, we cannot lose sight that these expressions are projected into the future, through imaginary and desire" (Abreu 2013: 181). In the fantastic world of the Aragwaksã the participants in the festival, as in raves, "revive the idea of a primordial community: the tribe" (Ibid).

In this transportation, people do not change their status. The event is characterized more as a form of enjoyment in a liminoid space - although the people can leave from there transformed by the efficacy inherent to collective experiences. The transport that takes place in the baptism at Jaqueira also establishes a negotiation concerning an unexpected form of power relations. The baptism itself is a poetic that inverts a colonially established relationship (as was so often enacted with the participation of the Pataxó in the Act of Discovery at Coroa Vermelha), because at Aragwaksã it is the Indians who baptize the children of the "whites".

For this to have dramatic success a "type of implicit contract" is required between the indigenous actors and their audience. As Pacheco emphasizes (2004), citing Schieffelin, there should be an "interactive credibility" that does not relate to the notion of belief, but to the "realization of a practice that can result in a certain state of spirit. In this sense, we can say that to act as if one believes is already believing" (Pacheco 2004: 218). As Mauss (1981) affirmed, the rite creates what it does and is self-sufficient. It has an immanent power.

But what does the Pataxó baptism create? According to Turner (1986), "all human act is impregnated with meaning, and meaning is hard to measure, though it can often be grasped, even if only fleetingly and ambiguously" (Turner 1986: 33). The Pataxó baptism is ambiguous and fleeting. It is not precise in substantive terms: it is art. It is, as Bauman (2008) said, an act of expression that calls attention to itself. 
But if the baptism is a "ritual" in Pataxó discourse, Schechner (2006) has taught us to not focus on the binary scheme of ritual or art, but to focus on the functions of the performance. If the Indians call it "ritual" (and also consider its aesthetic dimensions), it should also be asked: ritual for whom? To meet whose demand and for what? The Pataxós public certainly does not want to see acts based on the creation of individual authors, but an ethnic performance. The authorial nature of the individual and collective creations at Jaqueira does not stand out (and is certainly not displayed), because they must be presented as ethnic traditions that emanate from an anonymous collectivity and may be immemorial. Moreover, what the public wants to see as tribal ritual, the Pataxós perform as "work" (a professional option to jobs in the region). In addition, the baptism is a "ritual" that like the other activities in the sphere of work for tourists, is not separated from the ludic. This "ritual" play is internally important in the process of revitalization of the Pataxó culture.

I do not want to say that the Pataxó attempt to present the liminoid as the liminal; the intercultural entertainment as if it was the transformative efficacy of the rite of passage. This is simply not the case at Jaqueira, where all these possibilities are interlaced in the performances conducted there. Social and or aesthetic dramas provide the experience of the limen, from which powerful multivocal symbols emerge.

It is up to the Pataxó actors, in their regency, to conduct the audience towards an experience based on a certain script. This action should seek to transport people, if possible, to transformative experiences that bring about new meanings in relation to the reality under construction. They should construct a persuasive rhetoric (and I refer here both to the performance of oral and corporeal languages) (Csordas 2008) which, by breaking the canons of intelligibility naturalized in the quotidian discourse, creates the possibility for emergent meanings. The baptism at Aragwaksã is multivocal, it is open to multiple interpretations or meanings on the part of all the participants in the performance; whether they are actors, indigenous visitors or tourists. As a function of this polysemy, there is little point in asking anyone about the meaning of this rite, because it is multiple and its efficacy seeks the metaphoric transformation of the audience (including the indigenous one) by redirecting its attention to the Pataxó of Jaqueira. They strive to be seen through a new positioning of the look that reconstructs the meaning attributed to the Indians, their culture, traditions, history and nature. Rite-art, the baptism at Aragwaksã evokes the existence of meanings that are exterior to us, which flow beyond our understanding, and which have us recognize our semiotic immaturity.

Translated by Jeffrey Hoff

Received: June 26, 2016; Approved: November 18, 2016 


\section{References}

ABREU, Carolina de C. 2013. "Festa eletrônica pelos jardins do mundo: raves em terras brasileiras". In: John C. Dawsey et al. (orgs.), Antropologia e performance. Ensaios NAPEDRA. São Paulo: Terceiro Nome. pp. 163186.

ASAD, Talal. 1993. Genealogies of religion: disciplineand reasons of power in Christianity and Islam. Baltimore: The Johns Hopkins University Press.

BABCOCK, Barbara. 1999. "Subject to writing: the Victor Turner prize and the anthropological text". Antrhopology and Humanism [special issue], 24(2): 91-173.

BARRETTO, Margarita. 1995. Manual de iniciação ao estudo do turismo. Campinas: Papirus.

BARTH, Fredrik. 1984. "Problems of conceptualizing cultural pluralism, with illustrations from Somar, Oman”. In: D. Maybury-Lewis (ed.), The prospects for plural society.Washington, D.C.: The American Ethnological Society. pp. 77-87.

BAUMAN, Richard. 1975. "Verbal arts as performance". American Anthropologist, 77(2): 290-311. . 2008. "A poética do mercado público: gritos de vendedores no México e em Cuba". Antropologia em Primeira Mão, 103: 1-21.

BENJAMIN, Walter. 1994. "Doutrina das semelhanças". In: Magia e técnica, arte e política. Obras escolhidas: vol 1. São Paulo: Brasiliense. pp. 108-113.

BRUNER, Edward. 1986. "Experience and its expressions”. In: V. Turner \& E. Bruner (eds.), The anthropology of experience. Urbana and Chicago: University of Illinois Press. pp. 3-3o.

. 2004a. "Tourism in the Balinese borderzone". In: S. B. Gmelch (ed.), Tourists and tourism: a reader.

Long Grove: Waveland Press. pp. 219-238.

. 2004b. "The Maasai and the Lion King: authenticity, nationalism, and globalization in African

tourism”. In: S. B. Gmelch (ed.), Tourists and tourism: a reader. Long Grove: Waveland Press. pp. 127-156. . 2005. "Introduction: travel stories told and retold". In: Culture on tour: ethnographies of travel.

Chicago: The University of Chicago Press. pp. 1-29.

CHRONIS, Athinodoros. 2012 "Between place and story: Gettysburg as tourism imaginary". Annals of Tourism Research, 39(4): 1797-1816.

CLIFFORD, James. 1986. “On ethnographic allegory”. In: J. Clifford \& G. Marcus (eds.), Writing culture. Berkeley: University of California Press. pp. 98-121.

CSORDAS, Thomas. 2008. "A retórica da transformação no ritual de cura". In: Corpo/significado/cura. Porto Alegre: Editora UFRGS. pp. 29-100.

DAWSEY, John C. 2005a. "Victor Turner e a antropologia da experiência". Cadernos de Campo, 13: 163-176. . 2005b. "O teatro dos 'bóias-frias': repensando a antropología da performance". Horizontes Antropológicos, 24: 15-34.

DILTHEY, Wilhelm. 1976. Dilthey: selected writings. H. P. Rickman (ed.). Cambridge: Cambridge University Press.

EDENSOR, Tim. 2001. "Performing tourism, staging tourism: (re)producing tourist space and practice". Tourist Studies, 1(1): 59-81.

GEERTZ, Clifford. 1978. "Um jogo absorvente: notas sobre a briga de galos balinesa”. In: A interpretação das culturas. Rio de Janeiro: Zahar. pp. 278-321.

GEORGES, Robert. 1969. "Toward an understanding of storytelling in context". Journal of American Folklore, 82(326): 313-328.

GRÜNEWALD, Rodrigo de A. 2001. Os índios do descobrimento: tradição e turismo. Rio de Janeiro: Contra Capa. . 2002. "Tourism and cultural revival". Annals of Tourism Research, 29(4): 1004-1021.

. 2003. "Turismo e etnicidade”. Horizontes Antropológicos, 20: 141-159. 
. 2009. "The contingency of authenticity: intercultural experiences in indigenous villages of Eastern and Northeastern Brazil". Vibrant, 6(2): 52-80.

. 2012 "Staged indigeneity and the Pataxó". In: G. Lohmann and D. Dredge (eds.), Tourism in Brazil:

environment, management and segments. London: Routledge. pp. 158-172.

. 2014. "A 'Dança da Caça': performance e autenticidade". Raízes, 34(2): 85-99.

. 2015a. "Turismo na Terra Indígena Pataxó de Coroa Vermelha: imperialismo e pós-colonialidade na

região do descobrimento do Brasil". Pasos. Revista de Turismo y Patrimonio Cultural, 13(2): 411-424.

. 2015b. “Turismo pataxó: da renovação identitária à profissionalização das reservas”. Agália: Revista

de Estudos na Cultura. Número Especial: Turismo em Terras Indígenas. pp. 43-58.

KOROM, Frank J. 2013. "The anthropology of performance: an introduction”. In: The anthropology of performance: a reader. Oxford/Malden: Wiley-Blackwell. pp. 1-7.

LANGDON, Esther Jean. 2007. "Performance e sua diversidade como paradigma analítico: a contribuição da abordagem de Bauman e Briggs". Antropologia em Primeira Mão, 94: 5-17.

LOWENTHAL, David. 1985. The past is a foreign country. Cambridge: Cambridge University Press.

MacCANNELL, Dean. 1973. “Staged authenticity”. American Journal of Sociology, 79(4): 589-603.

. 1992. Empty meeting grounds. London: Routledge.

MAUSS, Marcel. 1981. “A prece”. In: R. C. de Oliveria (org.), Mauss. São Paulo: Perspectiva. pp: 102-146.

MOORE, Sally Falk. 1978. Law as process: an anthropological approach. London: Routledge \& Kegan Paul.

MORAES, Marcos V. M. 2013. "Mímesis e infância: notas sobre a construção de uma infância na escola de educação infantil”. In: John C. Dawsey et al. (orgs.), Antropologia e performance. Ensaios NAPEDRA. São Paulo: Terceiro Nome. pp. 129-146.

OBEYESEKERE, Gananath. 1981. Medusa's hair. An essay on personal symbols and religious experience. Chicago: University of Chicago Press.

PACHECO, Gustavo. 2004. Brinquedo de cura: um estudo sobre a pajelança maranhense. Tese de Doutorado em Antropologia Social, Programa de Pós-Graduação em Antropologia Social/Museu Nacional/ Universidade Federal do Rio de Janeiro - Rio de Janeiro.

ROSALDO, Renato. 1989. Culture and truth: the remaking of social analysis. Boston: Beacon Press.

SCHECHNER, Richard. 1985. Between theater \& anthropology. Philadelphia: University of Pennsylvania Press. . 1988. Performance theory. London and New York: Routledge.

. 2006. Performance studies: an introduction. Second edition. New York \& London: Routledge.

. 2013. “'Pontos de contato' revisitados”. In: John C. Dawsey et al. (orgs.), Antropologia e performance.

Ensaios NAPEDRA. São Paulo: Terceiro Nome. pp. 37-65.

SCHIEFFELIN, Edward. 1985. "Performance and the cultural construction of reality". American Ethnologist, 12(4): 707-724.

SILVA, Rubens Alves. 2005. "Entre 'artes' e 'ciências': a noção de performance e drama no campo das ciências sociais". Horizontes Antropológicos, 24: 35-65.

SINGER, Milton. 1972. When a great tradition modernizes: an anthropological approach to indian civilization. New York: Praeger Publishers.

STEIL, Carlos Alberto. 1996. O sertão das romarias: um estudo antropológico sobre o santuário de Bom Jesus da Lapa - Bahia. Petrópolis: Vozes.

TAUSSIG, Michel. 1993. Mimesis and alterity. New York: Routledge.

TAYLOR, Diana. 2013. “Traduzindo performance [prefácio]”. In: John C. Dawsey et al. (orgs.), Antropologia e performance. Ensaios NAPEDRA. São Paulo: Terceiro Nome. pp. 9-16.

TURNER, Victor. 1957. Schism and continuity in an African society: a study of Ndembu village life. Manchester: Manchester University Press. 
.1969. The ritual process. Chicago: Aldine.

. 1974. Dramas, fields, and metaphors. Itaha/London: Cornell University Press.

. 1982. From ritual to theatre. New York: PAJ.

. 1986. "Dewey, Dilthey, and drama: an essay in the anthropology of experience". In: V. Turner \& E.

Bruner (eds.), The anthropology of experience. Urbana and Chicago: University of Illinois Press. pp. 33-44. . 1987. The anthropology of performance. New York: PAJ.

VAN GENNEP, A. 1978. Os ritos de passagem. Petrópolis: Vozes.

\section{Rodrigo de Azeredo Grünewald}

Graduate Program in Social Sciences, Federal University of Campina Grande

E-mail: grunewald.ufcg@gmail.com 